\title{
THYROID EVALUATION IN HIV-1-INFECTED PATIENTS
}

THESIS. L. P. S. Sgarbi submitted this dissertation for her Masters in Tropical Diseases at Botucatu School of Medicine, São Paulo State University, UNESP, Botucatu, São Paulo, Brazil, 1998.

\section{Advisor: Professor Rinaldo Poncio Mendes}

\begin{abstract}
Reports on thyroid function in patients infected by the human immunodeficiency virus (HIV-1) have been scanty and contradictory. Until now, it has not been found any Brazilian publication about this subject. Thus, this study was carried out in order to evaluate the thyroid function at different stages of HIV-1 infection and to determine if the alterations in thyroid function tests could be useful to predict the progression of the disease and the patient outcome. Eighty-five HIV-1infected patients aging 17 to 63 years old (mean=32), and 16 healthy volunteers aging 17 to 62 years old (mean=36) participated in this prospective study. Total triiodothyronine (T3), total thyroxine (T4), free thyroxine (FT4), thyrotropin (TSH), responsiveness to thyrotropin-releasing hormone $(\mathrm{TRH})$, and $\mathrm{T}$ lymphocytes $\mathrm{CD}^{+}$ and $\mathrm{CD}^{+}$cells were measured. Individual variables were compared between four groups: Group I (GI) - 16 healthy volunteers; Group II (GII) - 30 HIV-1-infected individuals with more than 200 CD4+ cells/mm3; Group III (GIII) - 30 AIDS patients with 200 CD4+ cells/mm $\mathrm{mm}^{3}$ or less, and without opportunistic infection; Group IV (GIV) - 25 patients with $200 \mathrm{CD} 4+$ cells $/ \mathrm{mm}^{3}$ or less, and with opportunistic infection. There were 75 survivors and 10 deaths after three months of follow-up. The results showed that 53 patients $(62.3 \%)$ presented some kind of abnormality in the thyroid function tests. Primary hypothyroidism was found in 25 patients $(29.4 \%)$, and alterations compatible with euthyroid sick syndrome were observed in 28 patients $(32.9 \%)$. Serum T4 levels were not different between the groups, but serum T3 levels were lower in GIV patients $(p<0.001)$, and serum TSH levels were lower in GIII patients, when compared to healthy controls. There was a positive correlation between serum T3 levels and mortality $(p=0.004)$. Based on these results, it was possible to conclude that abnormalities in thyroid function tests are frequently observed in HIV-1-infected patients, and that a decline in serum T3 levels may provide a prognosis for this infection.
\end{abstract}

KEY WORDS: AIDS, HIV, hipothyroidism.

\section{CORRESPONDENCE TO:}

L. P. S. SGARBI, Departamento de Doenças Tropicais e Diagnóstico por Imagem, Faculdade de Medicina de Botucatu, UNESP, Distrito de Rubião Junior, s/n, 18618000, Botucatu, SP, Brasil. Phone: 55143811 6212. Email: rmendes@fmb.unesp.br. 